У, $\triangle \mathrm{K} 349.2$

ББК 67.405.1

DOI 10.22394/1682-2358-2019-5-70-78

A.A. Ivanov, Candidate of Sciences (Law), Senior Lecturer of the Labor Law Department, Saratov State Academy of Law

\section{FORCING A TEACHER TO VOLUNTARILY RESIGN: LEGAL ISSUES}

Labor relations between teachers and senior management of public education institutions are studied. Attention is paid to the analysis of labor law norms on termination of an employment contract. Aspects of forcing teachers to voluntarily resign are considered from the viewpoint of judicial practice.

Key words and word-combinations: compelling to voluntarily resign, mobbing, immoral misconduct.
А.А. ИВаноВ, кандидат юридических наук, стариий преподаватель кафедры трудового права Саратовской государственной юридической академии (email: artiom-depeche@yandex.ru)

\section{ПОНУЖАЕНИЕ ПЕААГОГА \\ К УВОАЬНЕНИЮ \\ ПО СОБСТВЕННОМУ ЖКААНИЮ: ПРАВОВЫЕ ВОПРОСЫ}

Аннотация. Исследуются трудовые отношения между педагогами и руководством общеобразовательных учреждений. Подвергаются анализу нормы трудового законодательства, посвященные расторжению трудового договора. В контексте судебной практики рассматриваются аспекты понуждения к увольнению по собственному желанию педагогических работников.

Ключевые слова и словосочетания: понуждение к увольнению по собственному желанию, моббинг, аморальный проступок.

K векикому сожкалению, профессия учителя общеобразовательного учреждения не явмяется престижной, и выпускники профильных вузов стараются не рассматривать возможность связать свою жизнь с работой в школе $[1 ; 2]$. ОАнако следует отдать домжное тем педагогам, которые вопреки различным факторам (Аалеко не молодой возраст, состояние зАоровья, стрессы и Ар.), и несмотря на невысокую заработную плату, а иногда и условиям труда, оставцяющем жекать цучшего, выполняют свою социально значимую миссию [3]. Тем не менее в сфере отношений межау работником (пе- 
Аагогом) и работодателем, осуществмяющим руководство образовательным учреждением, возникают ситуации понуждения педагога к увольнению по собственному желанию [4]. В связи с этим представляется необходимым провести исследование данной проблемы в следующих направлениях: во-первых, изучить явмение «моббинга» с правовых, практических и теоретических позиций применительно к отношениям межАу педагогами и директорами школ; во-вторых, изучить правовые аспекты, связанные с увольнением работника по собственному желанию исходя из положений Трудового кодекса Российской Федерации [5]; в-третьих, исследовать вопросы доказывания понуждения к увольнению по собственному желанию со стороны работодатеця; в-четвертых, изучить вопросы понуждения педагога к увольнению через призму конфцикта отношений межАу учитемем и родитемями учащихся или аморального проступка; в-пятых, исследовать аспект зашиты прав педагогов, подвергшихся давлению со стороны руководства образовательной организации.

В науке механизм понуждения к увольнению называется моббингом. Шведский исследователь Х. Аейман понимает поА моббингом психологический терроризм, проявляющийся в систематическом, враждебном отношении к человеку одного или нескольких мюдей в трудовом коммективе [6]. Специалисты выдемяют Ава вида моббинга: вертикальный (Аавмение исходит со стороны начальника) и горизонтальный (со стороны коммег). Моббинг может происходить как в открытой, так и матентной форме. Исследователи выделяют множество форм проявления моббинга, среди которых вербальная агрессия против сотрудника; постоянная дискуссия с работником с целью демонстрации своего превосходства; вспышки гнева, сопровождающиеся грубыми высказываниями, унижающими работника [7, с. 45] .

Представляется цемесообразным рассмотреть вопросы принуждения к увольнению по собственному жеканию сотрудника в контексте ТК РФ и материалов судебной практики. Статья 77 ТК РФ преАусматривает возможность работника расторгнуть трудовое соглашение по собственному жеканию. ОАнако понуждать его к написанию заявления на увольнение по собственному жеманию нельзя. В рамках закона работодатель по правилам ст. 80 ТК РФ может преАложить сотруднику расторгнуть трудовой Аоговор по соглашению сторон. Как отмечается в апемяяционном опредемении Алтайского краевого суда от 8 мая 2013 г. по делу № 33-3482/13, не имеет значения обстоятельство, от кого исходит такая инициатива [8]. ОАнако следует отметить, что это преАложение не должно содержать в себе угроз и иных формулировок, которые могут быть расценены как понуждение к увольнению. Суд также может принять во внимание отсутствие у работника мотиваџии дмя расторжения трудовых отношений, что чаще всего касается прекращения данных отношений с такими категориями работников, как беременные женщины и инвалиды. Как отмечается в определении Московского городского суда от 24 марта 2011 г. по делу № 33-8111, в данном случае указанные соџиально незащищенные граждане Аишаются установленных Амя них законом гарантий [9] .

На практике имеются ситуаџии, когда сотрудники неоднократно привлекаются к Аисџиплинарной ответственности, увольняются, а затем обращаются 
в суА, указав, что посреАством применения дисциплинарных взысканий работодатель вынудиц уволиться. В подобных случаях описанные Аействия, как отмечается в апемяџионном определении А^тайского краевого суда от 8 мая 2013 г. по Аелу № 33-3482/13, не могут расцениваться как Аавление [8] . Здесь работодателю следует доказать не только факт совершенного Аисципминарного проступка, но и то, что при применении взыскания учитывались тяжесть этого проступка и обстоятельства, при которых он был совершен, а также предшествующее поведение работника, его отношение к трудовым обязанностям [10, с. 109].

Заслуживает внимания и Аругая категория Аел, когда работник уволился Аобровоцьно, по собственному желанию, однако впоследствии обратился в суд с иском о принуждении работодателем к увольнению. В соответствии со ст. 80 ТК РФ в подобных случаях основным Аоказательством того, что работник уволицся по собственной воле, является его заявцение об увольнении, составленное в письменной форме. Как отмечается в кассаџионном определении Камчатского краевого суда от 22 декабря 2011 г. по делу № 33-1627/2011 г., если работодатель не представит в суд заявление работника об увомьнении, то работник будет восстановлен [11]. Работодателю следует быть внимательным к тексту заявления об увольнении, так как формулировка может выдавать вынужденность его подачи. На данный факт обращается внимание в постановмении Президиума Санкт-Петербургского городского суда от 5 апреля 2006 г. № 44г-153 [12] .

Представцяет интерес категория Аел, связанных с увольнением работников по собственному желанию из-за предшествующего конфликта с работодателем. Факт существования трудового конфиикта между начальством и сотруАником не является причиной понужАения к увольнению. Об этом говорится в апемцяџионном определении Суда Ханты-Мансийского автономного округа - Югры от 23 мая 2012 г. по деку № Н33-751/12 [13] . В подобных ситуациях, как отмечает другая судебная инстанџия, - Челябинский областной суд в своем апемляџионном определении от 19 июля 2013 г. по делу № 11-6959/2013 - работнику следует доказать факт того, что увольнение яв-

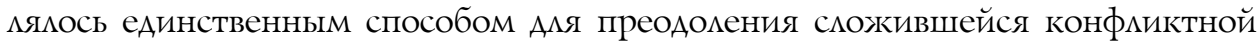
ситуации [14]. В защиту работодателя можно привести Аовод о том, что намичие конфликта между работником и работодателем не является основанием Аля увольнения сотрудника. Следовательно, работодатель можкет исходить из того, что до увольнения сотрудник не давац повода к расторжению сотрудничества, а свидетельские показания могут оказаться весомыми доказательствами данного факта.

Очевидно, давление на работника со стороны работодатемя по вопросу увольнения «по собственному желанию» не Аопускается. ОАнако следует учитывать, что не всегда Аействия работодателя изначально напоминающие принуждение, являются таковыми. Например, заслуживает внимания апекмяџионное определение Пермского краевого суда от 20 ноября 2017 г. по Аелу № 33-12841/2017 [15] . Водитель школьного автобуса прогуцяц работу, и руководство школы вместо того, чтобы применить соответствующие юриди-

72 Bulletin of the Volga Region Institute of Administration • 2019. Vol. 19. № 5 
ческие санкщии, предложило ему написать заявление об увольнении по собственному жеканию, дабы «не портить» трудовую книжку. Работник согласился, и увольнение было оформлено в тот же день. ОАнако после увольнения водитель обратияся в суА. В своей аргументаџии истеџ исходия из наличия конфликтной ситуаџии, возникшей межАу ним и работодателем. Истеџ утверждал о наличии факта заявления со стороны работодателя. Тем не менее водитель школьного автобуса проиграл судебный процесс, так как наличие конфликтной ситуации межАу указанными субъектами трудовых правоотношений не свидетельствовало в пользу вынужденности увольнения работника, потому что последний не был кишен возможности защитить свои трудовые права. Более того, применительно к данному делу отметим, что у работника был выбор - уволиться по собственному желанию в соответствии со ст. 77 ТК РФ или «по статье» - подразумевается соответствующий пункт ст. 81 ТК РФ. В Аанном случае от выбора работником основания расторжения трудовых отношений непосредственно зависело бы бремя доказывания, можашееся на стороны, в частности на работодателя. Исходя из п. 23 постановления Пценума Верховного Суда РФ от 17 марта 2004 г. № 2 [16], если бы работодатель уволик истца по правилам, предусмотренным Амя расторжения трудового договора по иниџиативе работодателя, то именно самому работодателю и пришлось бы доказывать наличие таковых оснований дмя увольнения работника через привлечение сотрудника к Аисциплинарной ответственности. Если же работник уволился по собственному желанию, а после заявиц, что вынужден был поступить таким образом из-за Аавления работодателя, то в таком случае он должен предоставить соответствующие доказательства данного факта. На этот момент также обращается внимание в постановлении Пиенума Верховного Суда РФ от 17 марта 2004 г. № 2. Согласно точке зрения практикующих специалистов, в подобных случаях у работников необходимых доказательств не бывает. В защиту прав работников можно отметить, что такие дела заканчиваются Аля них успехом, когАа проступок является мнимым, и работодатель не мог предоставить объективных доказательств [17, с. 82].

Цемесообразно проанализировать аспект доказывания факта понуждения к расторжению трудового договора по инициативе работника. Исходя из разъяснений, данных Пценумом Верховного Суда РФ при рассмотрении споров, связанных с расторжением трудовых отношений по инициативе работника, допускается в случае, когда заявление было подано на добровольных началах, по собственной воле работника. ОАнако, если истеџ исходит в своих доводах из того, что работодатель вынудиц его написать заявление по собственному желанию, то данный факт следует проверить, и обязанность его доказывания можится на работника. Следовательно, работник в силу ст. 55 и 56 Гражданско-процессуального кодекса РФ [18] Аомжен доказать факт понуждения к увольнению. В качестве таких доказательств могут быть требование работодателя в письменном виде об увольнении работника по собственному желанию; угрозы работодателя; показания свидетемей; аудио- и видеофиксация. В ^юбом случае доказательства должны быть получены в установленном законом порядке. Следует отметить, что данными способами работникам все же удается 
доказать свою правоту. Так, заслуживает внимания решение Кавалеровского районного суда Приморского края от 22 января 2010 г. [19]. Истеу в исковом заявлении отмечала, что в ноябре 2009 г. была вынуждена написать заявление об увольнении в порядке перевода на должность вахтера-уборщиџы. ОАнако в день написания такого заявления работниџа обратилась к руководству с заявлением о признании заявления об увольнении недействительным. Руководство заявление не приняло. Аля обоснования своей правоты истец предоставика показания свидетелей, подтвердившие факт принуждения к написанию заявления по собственному желанию. В результате суА удовлетвориц иск и восстановил истца в первоначальной должности [20, с. 116].

В педагогической деятельности конфликтные ситуаџии, возникающие межАу учителями и законными представителями учащихся не редкость. Но в таких случаях родители требуют от администрации школы расторжения трудового договора с работником (пеАагогом). Как показывает практика, подобные требования родитемей возникают из-за того, что учитель грубо и публично

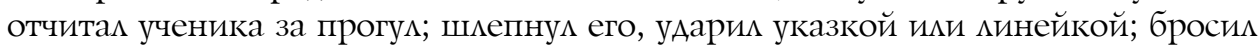
в него учебник или тетрадь; не выставиц рисунки ученика на конкурс, аргументировав свою мотивацию в грубой форме и т.А. Очевидно, что подобные действия могут быть квалифицированы с точки зрения законодательства в качестве проявлений психического или физического насилия (ст. 336 ТК РФ).

Российское законодательство не содержит мегальной дефиниџии физического и психического насилия. Обычно поА физическим насилием понимаются побои, а поА психическим - угрозы со стороны педагога в аАрес учашегося, оскорбления. Спещиалисты дополняют перечень деяний, которые можно назвать психическим насилием педагога над учеником, такими действиями, как завышенные требования к нему; постоянная негативная характеристика; демонстративное плохое отношение [21, с. 70]. В отношении такого педагога правомерно применить меры дисциплинарной ответственности от замечания до увольнения (ст. 192 ТК РФ), так и по правилам ст. 336 ТК РФ. Пункт 2 ст. 336 допускает увольнение, в том числе и за однократный случай такого насилия. Аля решения подобных ситуаџий следует создать комиссию, включающую завуча и председателя профсоюзной организаџии; истребовать объяснения в письменном виде с педагога и миџ, участвовавших в конфликте; а также сделать выводы и оформить решение комиссии.

ОАнако следует обратить внимание на обратную сторону медали: нередко недобросовестные родители, равно как и такие же недобросовестные ученики, умышленно провоцируют конфликт. Исходя из положений ТК РФ и Федерального закона от 27 декабря 2012 г. № 273-Ф3 «Об образовании в Российской Федераџии» [22], можно утвержАать, что педагог явмяется заведомо юридически скабой стороной в указанной ситуаџии и оказывается на грани увольнения [23].

Как известно, представители пеАагогической профессии, согласно положениям ТК РФ, явАяются субъектами трудовых отношений, наделенными особым статусом. Их можно уволить не только по общим, но и по специальным основаниям. Среди таких оснований закон выделяет совершение аморального

74 Bulletin of the Volga Region Institute of Administration • 2019. Vol. 19. № 5 
проступка, несовместимого с продолжением воспитательной работы (п. 8 ч. 1 ст. 81 ТК РФ) и применение, в том числе однократное, методов воспитания, связанных с физическим и (или) психическим насицием над мичностью обучающегося, воспитанника (п. 2 ст. 336 ТК РФ). ОАнако следует согласиться с исследователями в том, что в правоприменительной практике насилие и аморальный проступок зачастую перекцикаются [24, с. 83]. Показательным является определение Московского городского суда от 25 декабря 2015 г. № 4г-13859/2015. Так, в ходе урока физической культуры после неоднократных замечаний ученику педагог попытался поймать его за рукав, чтобы усадить его на скамейку и успокоить, но тот упац и получиц травмы. Аействия учителя были квалифицированы судом как аморальный проступок, в результате чего он не бым восстановлен на работе [25] .

Категория аморального проступка, предусмотренная ТК РФ, вызывает массу вопросов. В законодательстве не содержится мегальной дефиниции указанного понятия. Его состав неясен из-за отсутствия примерного перечня проступков [26, с. 11-12] . Следовательно когда возникают ситуации, связанные с совершением аморального проступка, именно руководитель образовательного учрежде-

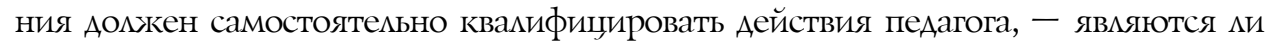
они аморальным проступком или нет. Кроме того, возникает закономерный вопрос, ^юбой $и$ проступок, связанный с нарушением закона, грубостью, насилием, можно считать аморальным? Исходя из обзора судебной практики напрашивается вывод о том, что суды выносят соответствующие решения, рассматривая дела через призму того, какой пример подают педагоги ученикам [27-31]. Анациз материалов судебной практики подтверждает, что суды в качестве критериев оценки аморальности проступка применяют прецеденты примеров поведения, которые педагог подал учащимся, а также пубцичный характер такого рода поступков. По первому критерию суды исходят из слеАующей установки: если поведение учителя негативно влияет на нравственное развитие учеников, то его следует считать аморальным. Тем не менее данный критерий вызывает вопросы. По могике судей и смыслу п. 8 ч. 1 ст. 81 ТК РФ можно уволить только тех субъектов трудовых отношений, которые занимаются воспитанием подрастающего поколения. Соответственно, миџа, входящие в состав обслуживающего персонала школы, не подлежат увольнению. ОАнако именно они с большей вероятностью, чем учителя, могут подавать дурной пример учащимся. Аанная категория работников не выполняет педагогической функции, и, соответственно, их нельзя будет привлечь к правовой ответственности [32; 16] . По второму критерию - публичности - аморальный проступок должен стать достоянием общественности. Считаем целесообразным дополнить указанные критерии третьим: общественный резонанс, который бым вызван противоправным деянием.

Таким образом, исходя из анализа материалов судебной практики, связанной с совершением педагогическими работниками аморальных проступков, можно отметить, что совершение аморального проступка не явцяется основанием увольнения педагога. На наш взгляА, применение мер Аисциплинарной 
ответственности к педагогам, совершившим аморальный проступок, Аолжно быть соразмерно содеянному.

На практике явления аморального проступка и насиция перекликаются. Например, заслуживает внимания апеммяџионное определение Красноярского краевого суда от 16 июня 2014 г. по деку № 33-4676/14, А-09 [33]. Учащийся в ходе урока труда стучал в окна мастерской, где педагог проводил занятие. Когда учитель выходиц из мастерской на шум, нарушавший учебный процесс ученик убегал и прятался. Когда учителю удалось поймать хулигана, несовершеннолетний нарушитель школьной Аисциплины, пытаясь вырваться и убежать, споткнулся о ступеньку и упац вместе с учителем. В результате учащийся получиц травмы. В соответствии со ст. 336 ТК РФ учитель был уволен. Тем не менее суд оправдал педагога, установив, что в действиях педагога не было умысла к совершению аморацьного проступка или физического насиция, ибо он своими действиями пытался предотвратить неправомерное поведение учащегося. Ученик утверждац, что учитель якобы ухватиц его за голову и трижАы удариц головой об стекло, но эти показания суА отклониц на основании показаний свидетелей, подтверАивших правоту учителя и воссоздавших объективную картину инџидента. Эти показания руководство школы не учло, когда принимало решение об увольнении. Следует также отметить, что увольнение учителя труда произошио в период его временной нетрудоспособности. Таким образом, руководством школы совершены следующие нарушения: в ходе служебного расследования не были опрошены все свидетели; не выявлена мотивация педагога. Следовательно, можно сделать вывод о том, что совершение аморального проступка (в определенных случаях связанного с психическим или физическим насилием) не является непосреАственным основанием к увольнению педагога; факт совершения проступка домжен быть объективно подтвержден соответствующими доказательствами; тем более выявцены конкретные обстоятельства, предшествующие совершению деяния, степень вины и отношение работника к трудовым обязанностям до совершения Аеяния.

Вопреки тому, что Федеральный закон 273-Ф3 акщентирует внимание на защите прав и интересов обучающихся и их законных представителей, педагог может защитить свои нарушенные права и избежать увольнения, к которому могут понужАать законные преАставители учащихся или аАминистрация образовательного учреждения. Исходя из положений Конституџии РФ педагоги имеют полное право защитить свои нарушенные трудовые права не запрещенными законом способами. Аанная конституционная норма находит свое развитие в ст. 352 ТК РФ, определяющей эти способы: правовая самозащита; обращение в профсоюзы; обращение в органы, осуществцяющие государственный надзор и контроль за соблюдением трудового законодательства; обращение в сул [34].

Таким образом, в результате проведенного исследования можно сделать следующие выводы. Во-первых, нацичие трудового конфцикта между работником и работодателем не явцяется основанием для увольнения сотрудника. Вовторых, в качестве доказательств понуждения к увоцьнению по собственному желанию могут быть требование работодателя в письменном виде; угрозы со 
стороны работодателя; показания свидетелей; аудио- и видео фиксация. Втретьих, суды в качестве критериев оџенки аморальности проступка считают пример, который пеАагог подал учащимся, а также его пубцичность. ПреАставляется џелесообразным дополнить указанные критерии третьим, а именно обшественный резонанс, который быц вызван деянием. В-четвертых, совершение аморального проступка не явмяется основанием увомьнения пеАагога. Безусловно, применение мер дисципиинарной ответственности к пеАагогам, совершившим аморальный проступок, должно быть соразмерно содеянному. B-пятых, на практике явление аморального проступка и насилия перекликаются. В-шестых, совершение аморального проступка (в определенных случаях психического или физического насилия) не является непосредственным основанием к увольнению педагога.

\section{Библиографический список}

1. Кто дойдет до школы. По данным Рособразования, в стране не хватает 50 тысяч учителей. URL: http://rg.ru/2005/08/23/shkola-pedagogi.html

2. Морозов Г.Б. Почему выпускники педагогических вузов не работают в образовательной cфepe? URL: http://gmanagement.ru/index.php/ru/arxiv/4-2016r/534-morozov2-102016

3. Ветхое будущее. Почему наши школы находятся в бедственном состоянии? URL: http:// aif.ru/society/educatiom/milliardy_na_shkolu_propashchie_i_obretyonnye

4. Куда подать жалобу на директора школы, который вынуждает учителя уволиться? URL: https://pravoved.ru/question/1454549/

5. Трудовой кодекс Российской Федерации от 30 дек. 2001 г. № 197-Ф3 (с изм. от 2 авг. 2019 г. № 292-Ф3) // С3 РФ. 2002. № 1 (ч. 1). Ст. 3.

6. Leyman H. The Content and Development of Mobbing at Work // European Journal of Work and Organizationally Psychology. 1996. № 5-2. Р. 165-184.

7. Третьяков Н.В. Психологические механизмы принуждения к увольнению (моббинг) и меры его профилактики // Медицинская сестра. 2015. № 2. С. 44-47.

8. Апелляционное определение Алтайского краевого суда от 8 мая 2013 г. по делу № 333482/13 [Электронный ресурс]. Доступ из СПС «Гарант».

9. Определение Московского городского суда от 24 марта 2011 г. по делу № 33-8111 [Электронный ресурс]. Доступ из СПС «Гарант».

10. Девяткова Ю. Работник утверждает, что его принудили к увольнению: как доказать правоту компании? // Кадровое дело. 2014. № 5. С. 108-113.

11. Кассационное определение Камчатского краевого суда от 22 дек. 2011 г. по делу № 331627/2011 [Электронный ресурс]. Доступ из СПС «Гарант».

12. Постановление Президиума Санкт-Петербургского городского суда от 5 апр. 2006 г. № 44г-153 [Электронный ресурс]. Доступ из СПС «Гарант».

13. Апелляционное определение Суда Ханты-Мансийского автономного округа - Югры от 23 мая 2012 г. по делу № Н33-751/12 [Электронный ресурс]. Доступ из СПС «Гарант».

14. Апелляционное определение Челябинского областного суда от 19 июля 2013 г. по делу № 11-6959/2013 [Электронный ресурс]. Доступ из СПС «Гарант».

15. Аппеляционное определение Пермского краевого суда от 20 нояб. 2017 г. по делу № 33-12841/2017 [Электронный ресурс]. Доступ из СПС «Гарант».

16. О применении судами Российской Федерации Трудового кодекса Российской Федерации: постановление Пленума Верховного Суда РФ от 17 марта 2004 г. № 2 (в ред. от 24 нояб. 2015 г.) // Бюллетень Верховного Суда РФ. 2007. № 3.

17. Слесарев С. Нет уж, увольте! // Директор школы. 2019. № 2. С. 76-88. 
18. Гражданско-процессуальный кодекс Российской Федерации от 14 нояб. 2002 г. № 138-Ф3 (с изм. от 26 июля 2019 г. № 213-Ф3) // СЗ РФ. 2002. № 46. Ст. 4532.

19. Решение Кавалеровского районного суда Приморского края от 22 янв. 2010 г. [Электронный ресурс]. Доступ из СПС «Гарант».

20. Щетиннкиова E. Понуждение к увольнению: трудности доказывания // Кадровое дело. 2011. № 8. C. 112-117.

21. Чуйков Д. Конфликт родителей с педагогом. Как действовать руководителю, чтобы не довести дело до суда // Справочник руководителя учреждения культуры. 2017. № 4. С. 68-72.

22. Об образовании в Российской Федерации: Федер. закон от 29 дек. 2012 г. № 273-Ф3 (с изм. от 26 июля 2019 г. № 232-ФЗ) // СЗ РФ. 2012. № 53 (ч. 1). Ст. 7598.

23. Обвинить и оболгать учителя может каждый. Безнаказанно и в чем угодно. URL: http:// ug.ru/article/ 145

24. Слесарев С. Аморальный проступок // Директор школы. 2018. № 7. С. 82-88.

25. Определение Московского городского суда от 25 дек. 2015 г. № 4г-13859/2015 [Электронный ресурс]. Доступ из СПС «Гарант».

26. Фатуев А. Изъяны в порядке прекращения трудового договора // Кадровик. Трудовое право для кадровика. 2010. № 1. С. 7-14.

27. Апелляционное определение Пензенского областного суда от 27 сент. 2016 г. по делу № 33-3457/2016 [Электронный ресурс]. Доступ из СПС «Гарант».

28. Апелляционное определение Верховного суда Республики Башкортостан от 18 авг. 2015 г. по делу № 33-12118/2015 [Электронный ресурс]. Доступ из СПС «Гарант».

29. Апелляционное определение Белгородского областного суда от 26 марта 2013 г. по делу № 33-1029 [Электронный ресурс]. Доступ из СПС «Гарант».

30. Апелляционное определение Московского городского суда от 26 нояб. 2014 г. по делу № 33-35067/2014 [Электронный ресурс]. Доступ из СПС «Гарант».

31. Апелляционное определение Камчатского краевого суда от 17 мая 2012 г. по делу № 35-654/2012 [Электронный ресурс]. Доступ из СПС «Гарант».

32. Постановление Президиума суда Ханты-Мансийского автономного округа - Югры от 14 авг. 2015 г. № 44 г-32/201 [Электронный ресурс]. Доступ из СПС «Гарант».

33. Апелляционное определение Красноярского краевого суда от 16 июня 2014 г. по делу № 33-4676/14 [Электронный ресурс]. Доступ из СПС «Гарант».

34. Фёклин С.И. О защите прав педагогических работников в случае трудового спора с работодателем // Администратор образования. 2013. № 4. С. 70-84. 